Article

\title{
Impact of Rice Straw Mulch on Soil Physical Properties, Sunflower Root Distribution and Yield in a Salt-Affected Clay-Textured Soil
}

\author{
Priya Lal Chandra Paul ${ }^{1,2, * \mathbb{D}}$, Richard W Bell ${ }^{1} \mathbb{D}$, Edward G. Barrett-Lennard ${ }^{1,3}$ and Enamul Kabir ${ }^{4}$ \\ 1 Land Management Group, Centre for Sustainable Farming Systems, Future Food Institute, \\ Murdoch University, Murdoch, WA 6150, Australia; r.bell@murdoch.edu.au (R.W.B.); \\ ed.barrett-lennard@dpird.wa.gov.au (E.G.B.-L.) \\ 2 Irrigation and Water Management Division, Bangladesh Rice Research Institute, Gazipur 1701, Bangladesh \\ 3 Department of Primary Industries and Regional Development, South Perth, WA 6151, Australia \\ 4 Agrotechnology Discipline, Khulna University, Khulna 9208, Bangladesh; ekabir73@yahoo.com \\ * Correspondence: plcpauliwm@yahoo.com; Tel.: +880-1716617378
}

\section{check for}

updates

Citation: Paul, P.L.C.; Bell, R.W; Barrett-Lennard, E.G.; Kabir, E. Impact of Rice Straw Mulch on Soil Physical Properties, Sunflower Root Distribution and Yield in a

Salt-Affected Clay-Textured Soil. Agriculture 2021, 11, 264. https:// doi.org/10.3390/agriculture11030264

Academic Editors

Alexander Gröngröft

and Marcella M. Giuliani

Received: 22 February 2021

Accepted: 17 March 2021

Published: 19 March 2021

Publisher's Note: MDPI stays neutral with regard to jurisdictional claims in published maps and institutional affiliations.

Copyright: (c) 2021 by the authors. Licensee MDPI, Basel, Switzerland. This article is an open access article distributed under the terms and conditions of the Creative Commons Attribution (CC BY) license (https:// creativecommons.org/licenses/by/ $4.0 /)$

\begin{abstract}
Puddling of clay soils for rice transplanting causes a loss of soil structure and vertical shrinkage cracks that are hypothesized to hamper sunflower root growth in the following dry season. To alleviate soil constraints for sunflower root growth and yield, we examined the effects of three levels of mulch and two irrigation regimes in the dry season on a clay-textured soil in the coastal zone of Bangladesh. These treatments were no-mulch, rice straw mulch at $5 \mathrm{tha}^{-1}$ and $10 \mathrm{t} \mathrm{ha}^{-1}$, irrigation applied to the field capacity (I1) and a water supply double that of the I1 treatment (I2). The rice straw mulch significantly increased soil water content by $3-9 \%$ and decreased soil penetration resistance by $28-77 \%$ and crack volume by $84-91 \%$ at A $0-30 \mathrm{~cm}$ soil depth relative to the no-mulch treatment. The better root development with the rice straw mulch increased sunflower yield by $23 \%$. No benefit or further reduction in soil penetration resistance or yield improvement was obtained from increasing the level of mulch from 5 to $10 \mathrm{t} \mathrm{ha}^{-1}$ or the volume of irrigation water. It is concluded that ameliorating soil constraints by mulch application led to better root growth in the upper root zone and the increased yield in the clay soil.
\end{abstract}

Keywords: crack dimension; soil water content; soil penetration resistance; sunflower yield

\section{Introduction}

In the salt-affected coastal zone of the Ganges delta, as in many parts of Asia that grow wetland rice, puddling of clay soil through intensive tillage for rice establishment in the wet season damages soil structure, which during the following dry season leads to massive blocks of soil separated by abundant vertical shrinkage cracks [1,2]. The puddled soils typically have an apedal structure, a compacted layer below the puddled layer and high soil strength when soil water decreases during the dry season [3,4]. An ideal soil pore space usually holds $25 \%$ water and $25 \%$ air by volume, but soil compaction due to puddled tillage with the dispersion of soil aggregates reduces the pore space in the dry season, which causes a dense soil with impeded internal drainage and aeration [5]. As a result of the lowered porosity and deficiency of oxygen in compacted soils, expansion of the root tip is impaired, which decreases root penetration and elongation and results in poor plant growth and development [6,7]. Cook [8], who conducted experiments in clay soil in growth chambers and the field at Los Banos, in the Philippines, reported that high soil penetration resistance in dry soil was the major soil physical constraint affecting the seedling emergence of mungbean (Vigna radiata L. R. Wilczek). So and Woodhead [9] reported that increasing soil mechanical resistance decreased the root elongation of legume species such as soybean (Glycine max), and root growth ceased when soil resistance was greater than $3 \mathrm{MPa}$. Goodman and Ennos [10] found that sunflower (Helianthus annus L.) 
and maize (Zea mays L.) growing in strong (bulk density: $1.4 \mathrm{Mg} \mathrm{m}^{-3}$ ) and weak soil (bulk density: $1.0 \mathrm{Mg} \mathrm{m}^{-3}$ ) had no difference in the number or weight of first-order lateral roots, but there was a significant effect on the fresh and dry weights of shoots of both species. Another experiment conducted by Bayhan [5] reported that root development and growth of sunflower were reduced by about $22 \%$ with a soil penetration resistance of $1.6-1.8 \mathrm{MPa}$ $(0-20 \mathrm{~cm})$ caused by wheel traffic.

In soils of the Ganges Delta, the predominant clay minerals are smectite and mica [11], and the drying of these can cause soil shrinkage and vertical cracking [12]. Cracks in the soil can cause bypass water flow from the soil surface to depth after rain or irrigation and can also cause an increase in water loss from soil profiles because greater soil surface area is more exposed to evaporation [13]. After irrigation, water moves quickly into crack networks and irrigation water can be lost from the root-zone through sub-soil infiltration and lateral drainage $[13,14]$. Cracks in the soil profile are said to impair the development and distribution of roots and grain yield [15-17], but effects may vary between crops. For example, there are also reports that soybean (Glycine max) roots can grow down crack walls and extract deeper subsoil water [18].

In this above study, measurements were made of water extraction by roots growing adjacent to soil cracks to $60 \mathrm{~cm}$, but measurements were not made of the effects of cracks on root dry weight, total root length or root density at different depths in the soil profile. The application of straw mulch to a soil surface can stimulate the restoration of soil structure in compacted soils $[19,20]$. For instance, mulches increased soil water content, stabilized soil aggregation and improved infiltration rate, all of which can prevent or mitigate the increase in soil penetration resistance [21,22]. Studies have shown that straw mulch is effective in increasing soil water content [20], thus reducing soil compaction [23] and crack development [12] and improving crop productivity [24]. With sunflowers, previous studies have investigated the effect of soil compaction on root growth and yield [5,25], but there have been no detailed studies on sunflower root distribution in the soil profile under compacted and cracking conditions in clay-textured soils. A recent study conducted by [20] showed that mulching with rice straw increased sunflower yield, and this was attributed to increased soil water and a lower $\mathrm{EC}_{1: 5}$ in surface soil layers, but the effects on root growth in this work were not reported. Although increases in soil penetration resistance have been reported to affect plant growth and root development in the literature, little work has been carried out on the sunflower root distribution in the soil profile in the saline clay-textured soils which are prevalent in the Ganges delta. Therefore, this study aimed to determine the effect of rice straw mulch together with different amounts of irrigation water on soil penetration resistance, crack dimension and sunflower root distribution in the profile of clay soil with a shallow water table.

\section{Materials and Methods}

\subsection{Site Description}

The experiment was established in a farmer's field at Pankhali, Dacope Khulna Bangladesh $\left(22^{\circ} 37^{\prime} 55^{\prime \prime} \mathrm{N}\right.$ and $\left.89^{\circ} 30^{\prime} 10^{\prime \prime} \mathrm{E}\right)$ from December 2018 to April 2019. This area is low-lying with an elevation 2-3 m above mean sea level [26] within the Ganges Tidal Floodplain agro-ecological zone [2]. The climate in this region is sub-tropical, with an average annual rainfall of $\sim 1800 \mathrm{~mm}$ of which $\sim 80 \%$ fall in the wet season. There is a cool dry winter from November to February and a hot and humid summer from March to June. During the study period, there was no rainfall from the beginning of the season until 22 February, but from flowering to maturity about $352 \mathrm{~mm}$ of rain was recorded (Figure 1). About half of the total seasonal rainfall occurred in the last week of February which inundated the plots. The temperature was lower in December and January (minimum average $12-14{ }^{\circ} \mathrm{C}$ ) and higher in March and April (maximum average $31.8-33.9^{\circ} \mathrm{C}$ ). The lowest and highest temperatures were $8{ }^{\circ} \mathrm{C}$ and $35.5^{\circ} \mathrm{C}$ in December and April, respectively (Figure 1$)$. The soil texture is a silty clay $(0-15$ and $15-30 \mathrm{~cm})$ overlying clay $(30-45$ and $45-60 \mathrm{~cm}$ ). The details of soil properties at $0-60 \mathrm{~cm}$ soil depth are shown in Table 1. A 
medium duration high-yielding monsoon-season rice variety was grown in the wet season and was harvested in the third week of November. The excess standing water on the land was removed by surface drainage to prepare the plots for sunflower planting. Irrigation water was conserved in an adjacent canal by constructing an embankment between the river and canal before the river water turned saline.

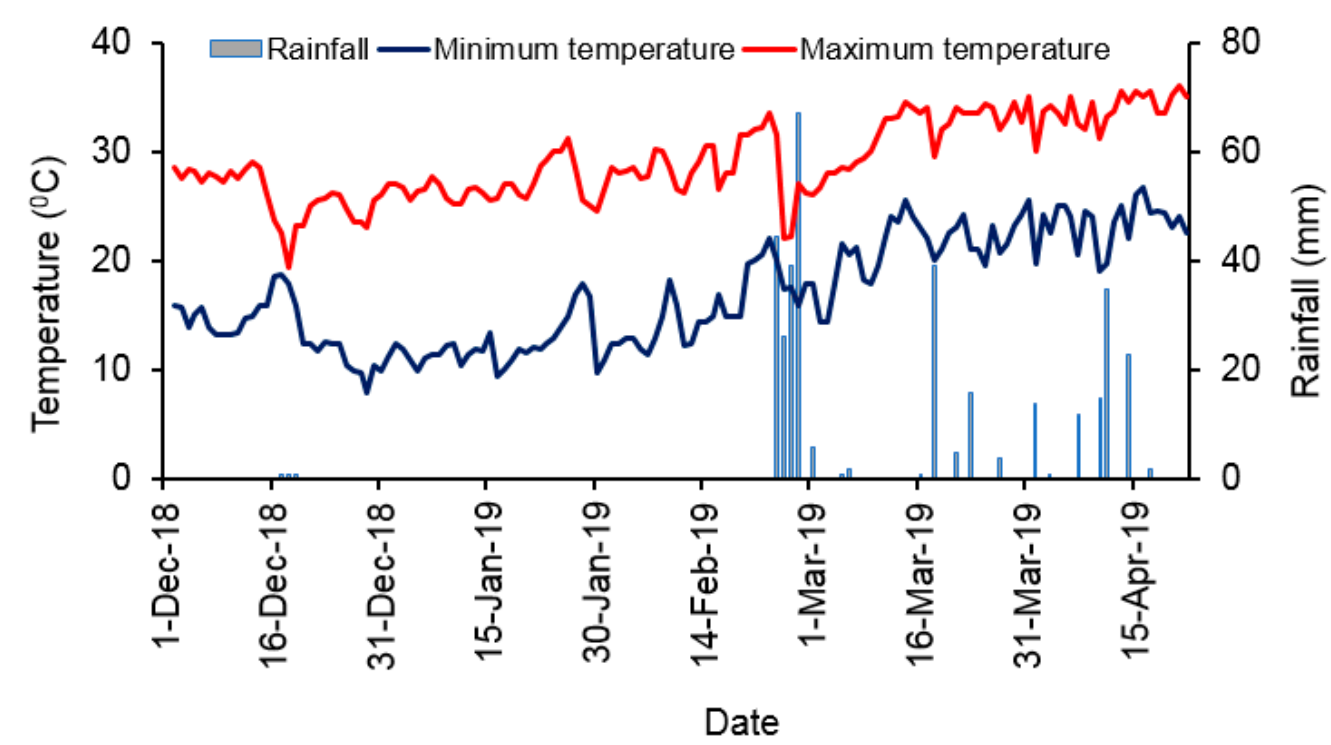

Figure 1. Weather details (daily rainfall, minimum and maximum temperature) for the 2018-2019 growing season at Pankhali, Dacope Khulna, Bangladesh.

Table 1. Physicochemical properties of the soil in Pankhali, Dacope, Khulna, Bangladesh in 2018-2019.

\begin{tabular}{|c|c|c|c|c|c|c|c|c|c|c|}
\hline \multirow{3}{*}{$\begin{array}{l}\text { Depth } \\
\text { (cm) }\end{array}$} & \multirow{3}{*}{$\mathrm{pH}$} & \multirow{3}{*}{$\begin{array}{c}\mathrm{EC}_{1: 5} * \\
\mathrm{dS} \mathrm{m} \mathrm{m}^{-1}\end{array}$} & \multirow{3}{*}{$\begin{array}{c}\begin{array}{c}\text { Bulk Density } \\
\left(\mathrm{Mg} \mathrm{m}^{-3}\right)\end{array} \\
\mathrm{g} \mathrm{cm}^{-3}\end{array}$} & \multirow{3}{*}{$\begin{array}{c}\text { Organic } \\
\text { C } \\
\left(\mathrm{g} \mathrm{kg}^{-1}\right)\end{array}$} & \multirow{3}{*}{$\begin{array}{c}\text { Total N (g } \\
\left.\quad \mathrm{kg}^{-1}\right)\end{array}$} & \multicolumn{4}{|c|}{ Extractable } & \multirow{3}{*}{ Soil Texture } \\
\hline & & & & & & $\mathbf{P}$ & $S$ & B & $\mathrm{Zn}$ & \\
\hline & & & & & & \multicolumn{4}{|c|}{$\left(\mathrm{mg} \mathrm{kg}^{-1}\right)$} & \\
\hline $0-15$ & 7.1 & 0.38 & 1.39 & 13 & 14 & 3.2 & 88 & 1.3 & 0.80 & Silty clay \\
\hline $15-30$ & 7.4 & 0.32 & 1.55 & 9 & 12 & 2.0 & 66 & 1.2 & 0.82 & Silty clay \\
\hline $30-45$ & 7.6 & 0.39 & 1.50 & 7 & 11 & 2.5 & 60 & 1.3 & 0.83 & Clay \\
\hline $45-60$ & 7.4 & 0.42 & 1.45 & 7 & 10 & 2.6 & 72 & 1.4 & 0.81 & Clay \\
\hline
\end{tabular}

${ }^{*} \mathrm{EC}_{1: 5}$ is the electrical conductivity $\left(\mathrm{dS} \mathrm{m}{ }^{-1}\right)$ of the $1: 5$ soil: water extract.

\subsection{Experimental Treatments and Crop Management}

The experiment tested three mulching treatments: no-mulch (NM), rice straw mulch at $5 \mathrm{t} \mathrm{ha}^{-1}$ (RS5) and rice straw mulch at $10 \mathrm{tha}^{-1}$ (RS10), and two irrigation regimes: I1 (water was applied to raise soil water to field capacity at 30,55 and 70 days after sowing (DAS)) and I2 (water applied at double the amounts of treatment I1 at 30, 55 and 70 DAS). The experiment was laid out in a split-plot design with three replications where irrigation was in the main plots and mulch in subplots. The plot size was $7 \times 5 \mathrm{~m}$, and sunflower seeds (cv. Hysun-33, hybrid) were dibbled into the un-tilled wet soil on 7 December by making a hole with a round stick to a depth of $2-3 \mathrm{~cm}$. There was a plant-to-plant spacing of $40 \mathrm{~cm}$ and a row-to-row spacing of $70 \mathrm{~cm}$. Plots were surrounded by thick polythene sheets inserted vertically beside a bund to $50 \mathrm{~cm}$ depth. In addition, a $1 \mathrm{~m}$ buffer zone between plots was maintained in order to prevent runoff or lateral seepage of irrigation water. The locally collected rice straw mulch was placed on the soil surface at 15 DAS (days after sowing). The fertilizer application was at 200, 200, 170, 170, 10 and $12 \mathrm{~kg} \mathrm{ha}^{-1}$ as urea, triple superphosphate, muriate of potash, gypsum, zinc sulphate and boric acid. All fertilizers except $75 \%$ of the urea were applied at sowing by adding to a hole 
(5-7 cm deep) on both sides of the plant ( $\sim 5 \mathrm{~cm}$ distance) along the rows; the rest of the urea was top-dressed in equal splits during the irrigation events. For pre-plant weed control, Roundup $^{(\mathrm{R})}$ (Glyphosate 62\%) was sprayed (1.5 litre per hectare) seven days before sowing and a hand weeding was carried out at 25 DAS. Nitro (Cypermethrin Chlorpyriphos) was sprayed (0.6 litre per hectare) three times during the season to control hairy caterpillar. Figure 2 shows the soil crack formation and crop performance under the three mulching treatments. Before maturity, an overhead net was set up to prevent damage to crops by birds. Physiological maturity was determined when all seeds had turned black and shiny. At harvest, $6 \mathrm{~m}^{2}$ was selected in the middle of the plots in each replication to measure head diameter, number of seeds per head and thousand seed weight. Final grain yield was calculated $\left(\mathrm{t} \mathrm{ha}^{-1}\right)$ at an adjusted moisture content of $9 \%(w / w)$.

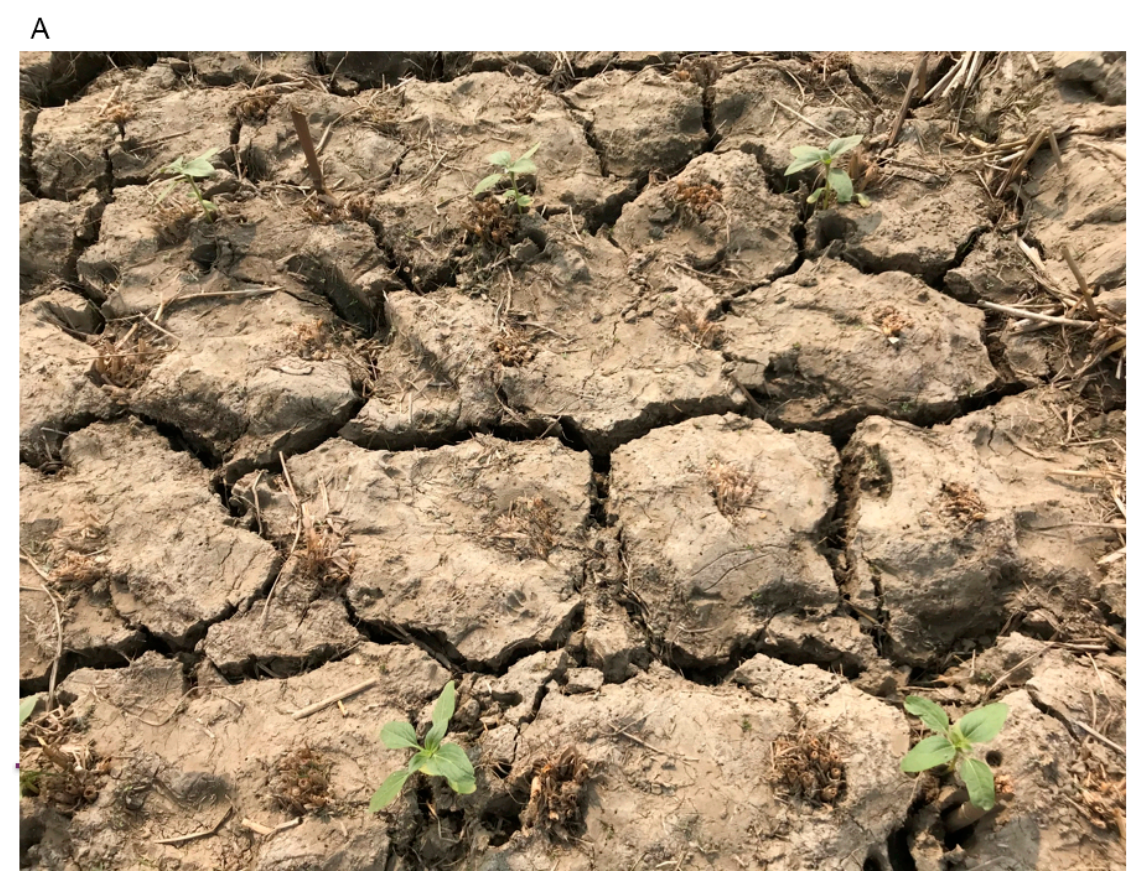

B

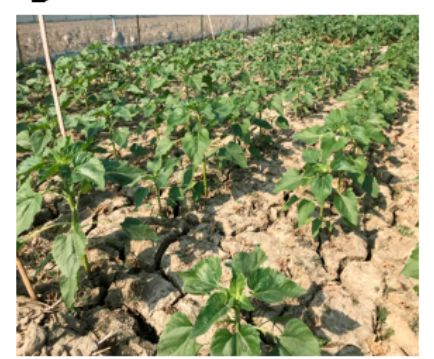

C

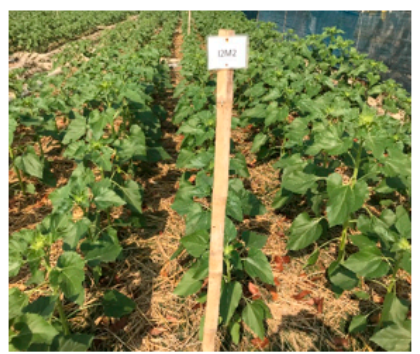

D

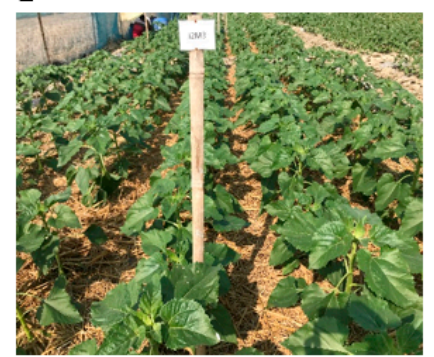

Figure 2. Pictorial view of cracked soil during sunflower growth (A) and the effects of mulch treatments on sunflower growth: (B) no-mulch, (C) mulch at $5 \mathrm{t} \mathrm{ha}^{-1}$, and (D) mulch at $10 \mathrm{t} \mathrm{ha}^{-1}$.

\subsection{Soil Water Content and Irrigation Water Requirement}

Soil samples were collected at $0-7,7-15,15-30,30-45$ and $45-60 \mathrm{~cm}$ depths at twoweek intervals between sowing and harvest to measure gravimetric soil water content (SWC). A hand-held auger was used to collect samples from each depth, and soils were placed immediately in sealable polyethylene bags. The wet weight of the samples was measured immediately, and they were then oven-dried at $105^{\circ} \mathrm{C}$ for about $48 \mathrm{~h}$ to obtain a constant weight. The SWC was calculated from the difference between soil wet and dry weight.

The gravimetric soil water content over the upper $60 \mathrm{~cm}$ of the soil was $33-35 \%$ at field capacity and $22-25 \%$ at wilting point. Irrigation water was applied by hose pipe during 
urea top dressing at 30, 55 and 70 DAS. The amount of irrigation water requirement was calculated based on the following Equation (1) [27]:

$$
(I)=\sum_{n=i}^{n} \frac{P_{w i} A_{s i} D_{i}}{100}
$$

where $I$ is the depth of irrigation water to be applied with one irrigation cycle (mm), $A_{s i}$ is bulk density of the $i^{\text {th }}$ layer of the soil, $D_{i}$ is the depth of the $i^{\text {th }}$ layer of the soil profile within the root zone to be irrigated (mm), $P_{w}=$ FC-RL; FC is mean soil water content at field capacity $(\%, w / w)$, RL is residual soil water level before each irrigation in the $i^{\text {ith }}$ layer of the soil profile $(\%, w / w)$ and $\mathrm{n}$ is a number of soil layers in the root zone depth.

\subsection{Soil Penetration Resistance}

After sowing, soil penetration resistance was measured using a cone penetrometer (Hand penetrometer Eijkelkamp) at the 0-7, 7-15 and 15-30 cm depths. Different sizes of cones ( 1 to $5 \mathrm{~cm}^{2}$ base area) were fitted to the extension rod as required to ensure that a uniform pressure could be applied to push the cone into the soil. In each measurement, the manometer reading in $\mathrm{kN}$ was recorded. The resistance was then calculated based on the surface area of the cone (manometer reading, $\mathrm{kN} /$ base area of cone, $\mathrm{cm}^{2}$ ), and finally the values were converted to $\mathrm{MPa}$.

\subsection{Soil Crack Dimension}

Soil surface cracks were measured in each plot using a transect method [15]. The transect involves a series of six connected semi-circles of $1 \mathrm{~m}$ diameter. Each semi-circle was placed on the soil surface, and the number of intercepts was recorded to measure the length of crack per unit area of soil surface $\left(\mathrm{L}_{\mathrm{A}}, \mathrm{m} \mathrm{m}^{-2}\right)$. The average depth $(\mathrm{D})$ and width $(\mathrm{W})$ of cracks intercepted by each semi-circle were counted from the first five cracks using a flexible ruler. Depth measurements were made by inserting the ruler gently into the cracks until the bottom was reached. The mean cross-sectional area $(\bar{X})$ of cracks (assuming a triangular cross-section) was calculated using the average depth and width $\left(\bar{X}=\frac{\text { depth } \times \text { width }}{2}\right)$. Finally, the volume of the crack per unit area $\left(\mathrm{V}_{\mathrm{A}}\right)$ was estimated as $\mathrm{L}_{\mathrm{A}} \times \overline{\mathrm{X}}$.

\subsection{Root Measurements}

Sunflower root distribution in the soil profile was observed at 25, 58 and 90 DAS (soil samples were taken in $20 \times 20 \mathrm{~cm}$ square blocks based on a plant-to-plant spacing of $40 \mathrm{~cm}$ ). At 25 DAS (seedling stage), shoots were separated from four selected plants in each plot, and the roots of each plant were excavated to a depth of $20 \mathrm{~cm}$ (maximum root length was at $15-20 \mathrm{~cm}$ soil depth). One plant was selected in each plot at 58 DAS (stage of maximum vegetative growth) and at 90 DAS (flowering stage). Shoots were excised and roots were excavated in a block $20 \mathrm{~cm}$ along the row, $20 \mathrm{~cm}$ across the row and at $20 \mathrm{~cm}$ deep increments to $60 \mathrm{~cm}$ at 58 DAS (root length was visible up to $60 \mathrm{~cm}$ ) and down to $80 \mathrm{~cm}$ at 90 DAS (root length was visible up to $80 \mathrm{~cm}$ ). Each block of soil was soaked in a bucket for 5-6 h. Roots were then separated from the slurry and washed out on a $2 \mathrm{~mm}$ sieve. Finally, the non-root materials were picked out from the samples. For each soil block, total root length (TRL) was measured manually using a ruler. Root dry weight (RDW) was measured after oven drying at $65^{\circ} \mathrm{C}$ to reach a constant weight. Root length density (RLD) (root length/soil volume) and specific root length (SRL) (root length/ root dry weight) were then calculated for each soil depth.

\subsection{Statistical Analyses}

The data for yield parameters were analysed with two-way (mulch and irrigation) ANOVA using STAR software (Version 2.0.1). The effects of mulch and irrigation on soil water content, penetration resistance and crack properties were determined using four- 
way factorial ANOVA models that also took account of the effects of soil depth and date after sowing (time) as repeated measures. The comparison of means was tested using the least significance difference (LSD) at the 95\% confidence level. The relationship between yield and soil parameters (soil water content, soil resistance and crack properties) were performed by Pearson's test.

\section{Results}

\subsection{Sunflower Yield and Yield Components}

The interaction of mulch and irrigation did not affect the yield and yield components (Table 2). However, mulch treatments significantly increased grain yield and yield components (Table 2). The RS5 and RS10 treatments had a $0.5-0.6 \mathrm{t} \mathrm{ha}^{-1}$ higher yield than the NM treatment. With the RS5 and RS10 treatments, thousand seed weight, number of seeds per head and head diameter were significantly higher relative to the NM treatment (Table 2). However, there was no difference in yield or yield components between the RS5 and RS10 treatments. Irrigation treatments did not affect the yield and yield components except thousand seed weight, which was higher in the I2 treatment than the I1 treatment (Table 2).

Table 2. Yield and yield attributes of sunflower under different mulch treatments and irrigation regimes in Pankhali, Dacope, Bangladesh in 2018-2019.

\begin{tabular}{|c|c|c|c|c|c|}
\hline Irrigation Regimes & $\begin{array}{c}\text { Mulch } \\
\text { Treatments }\end{array}$ & Yield (t ha $\left.{ }^{-1}\right)$ & $\begin{array}{c}\text { Thousand Seed } \\
\text { Weight (g) }\end{array}$ & Seeds per Head & Head Diameter $(\mathrm{cm})$ \\
\hline \multirow{3}{*}{ I1 } & RS10 & 3.1 & 82.0 & 1505 & 20.4 \\
\hline & RS5 & 3.0 & 81.5 & 1479 & 20.3 \\
\hline & NM & 2.5 & 74.0 & 1285 & 18.6 \\
\hline \multirow{3}{*}{ I2 } & RS10 & 3.3 & 87.0 & 1582 & 21.1 \\
\hline & RS5 & 3.2 & 84.5 & 1557 & 20.6 \\
\hline & NM & 2.8 & 79.0 & 1345 & 19.2 \\
\hline \multicolumn{6}{|c|}{ Treatment means } \\
\hline I1 & & 2.9 & 79.0 & 1423 & 19.8 \\
\hline I2 & & 3.1 & 84.0 & 1495 & 20.3 \\
\hline RS10 & & 3.2 & 85.0 & 1544 & 20.8 \\
\hline RS5 & & 3.1 & 83.0 & 1518 & 20.5 \\
\hline NM & & 2.6 & 76.5 & 1315 & 18.9 \\
\hline \multicolumn{6}{|l|}{$p$-values } \\
\hline Irrigation & & NS & 0.05 & NS & NS \\
\hline Mulch & & 0.05 & 0.05 & 0.01 & 0.05 \\
\hline Irrigation $\times$ Mulch & & NS & NS & NS & NS \\
\hline \multicolumn{6}{|l|}{$\mathrm{LSD}_{0.05}$} \\
\hline Irrigation & & - & 2.0 & - & - \\
\hline Mulch & & 0.3 & 6.2 & 109 & 1.3 \\
\hline Irrigation $\times$ Mulch & & - & - & - & - \\
\hline
\end{tabular}

I1 = irrigation up to field capacity; I2 = irrigation double that in treatment I1; NM = no-mulch; RS5 = rice straw $\sim 5 \mathrm{t} \mathrm{ha}^{-1}$; $\mathrm{RS} \mathrm{N}=$ rice straw $\sim 10 \mathrm{tha}^{-1}$; NS = non-significant.

\subsection{Soil Water Content}

The interaction of mulch and irrigation and irrigation treatments did not affect the SWC. However, the SWC was significantly affected by mulch treatments, soil depth and date after sowing (time), and there was a significant interaction between mulch and time (Figure 3A) and mulch and soil depth (Figure 3B). On 5 January, the SWC did not vary among the mulch treatments. The SWC was significantly lower from 20 January to 16 February in the NM treatment (22-33\%) than with the RS5 and RS10 treatments (28-36\%) (Figure 3A). From flowering to maturity (6 to $28 \mathrm{March}$ ), the SWC did not differ between treatments due to the seasonal rainfall. The greater change of SWC was at 0-30 cm, and below this depth there was little change (Figure 3B). The average SWC was high (31-34\%) 
at $0-15 \mathrm{~cm}$, decreased to about $29 \%$ at $30 \mathrm{~cm}$ and then increased again (33\%) at $60 \mathrm{~cm}$. The RS5 and RS10 treatments had significantly higher SWC at 0-30 cm depth than the NM treatment.
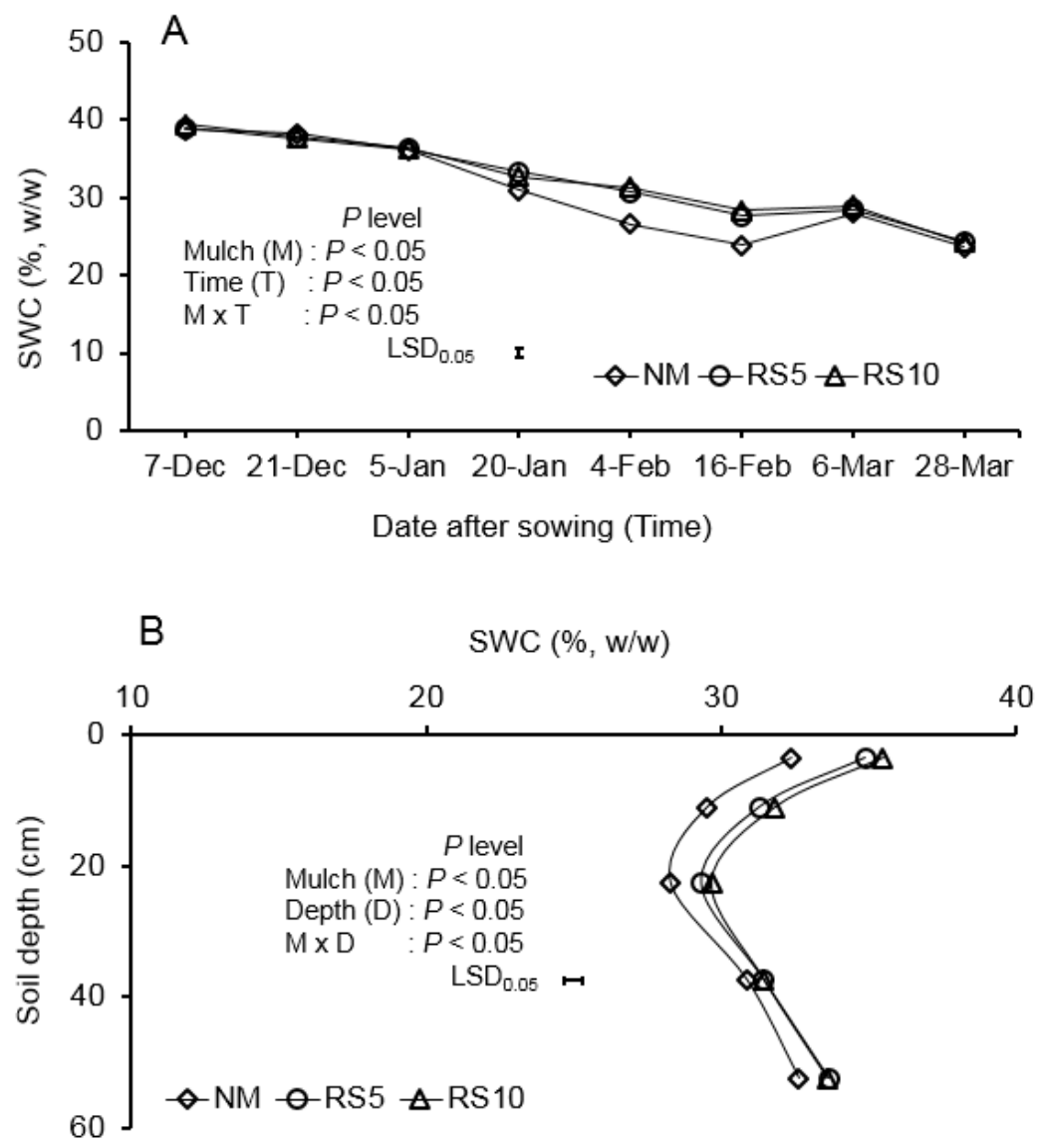

Figure 3. Effects mulch on soil water content (SWC) in the 2018-2019 season: (A) effect of mulch and the interaction between mulch and time and $(\mathbf{B})$ interaction between mulch and soil depth. LSD $_{0.05}$ is the least significant difference of the interaction between mulch and time (A) or mulch and soil depth (B). Part A is the average for the five soil depths. Part B is the average of values at eight times. $\mathrm{NM}=$ no-mulch; RS5 = rice straw at $\sim 5 \mathrm{tha}^{-1} ; \mathrm{RS10}=$ rice straw at $\sim 10 \mathrm{tha}^{-1}$.

\subsection{Soil Penetration Resistance}

After crop establishment, there was an increasing trend of soil penetration resistance in all mulching treatments; however, rice straw mulch significantly limited the increase in soil penetration resistance (Figure 4). From the first week of January, soil penetration resistance was two-fold higher without mulch (NM treatment) than with mulch (RS5 and RS10 treatments), but there was no difference between the RS5 and RS10 treatments (Figure 4A-C). With the NM treatment, the average soil penetration resistance was highest $(\sim 5.2 \mathrm{MPa})$ at $0-7 \mathrm{~cm}$ and lower $(2.8$ and $3.1 \mathrm{MPa})$ at $7-15$ and $15-30 \mathrm{~cm}$ depth on 30 January (Figure $4 \mathrm{~A}-\mathrm{C}$ ). By contrast, with RS5 and RS10 treatments, the average soil resistance was lowest (1.0 MPa) at $0-7 \mathrm{~cm}$ and increased to 1.8 and $2.1 \mathrm{MPa}$ at $7-15$ and $15-30 \mathrm{~cm}$. Throughout the season, the average soil resistance was smaller by $77 \%, 49 \%$ and $28 \%$ at 0-7, 7-15 and 15-30 cm depths, respectively, with the RS5 and RS10 treatments compared to the NM treatment. Irrigation treatments had no effect on soil resistance. There was a significant negative correlation between soil resistance and SWC (Figure 5). Soil resistance increased with decreasing SWC, and about $62 \%$ of the variation in soil resistance could be explained by SWC. 


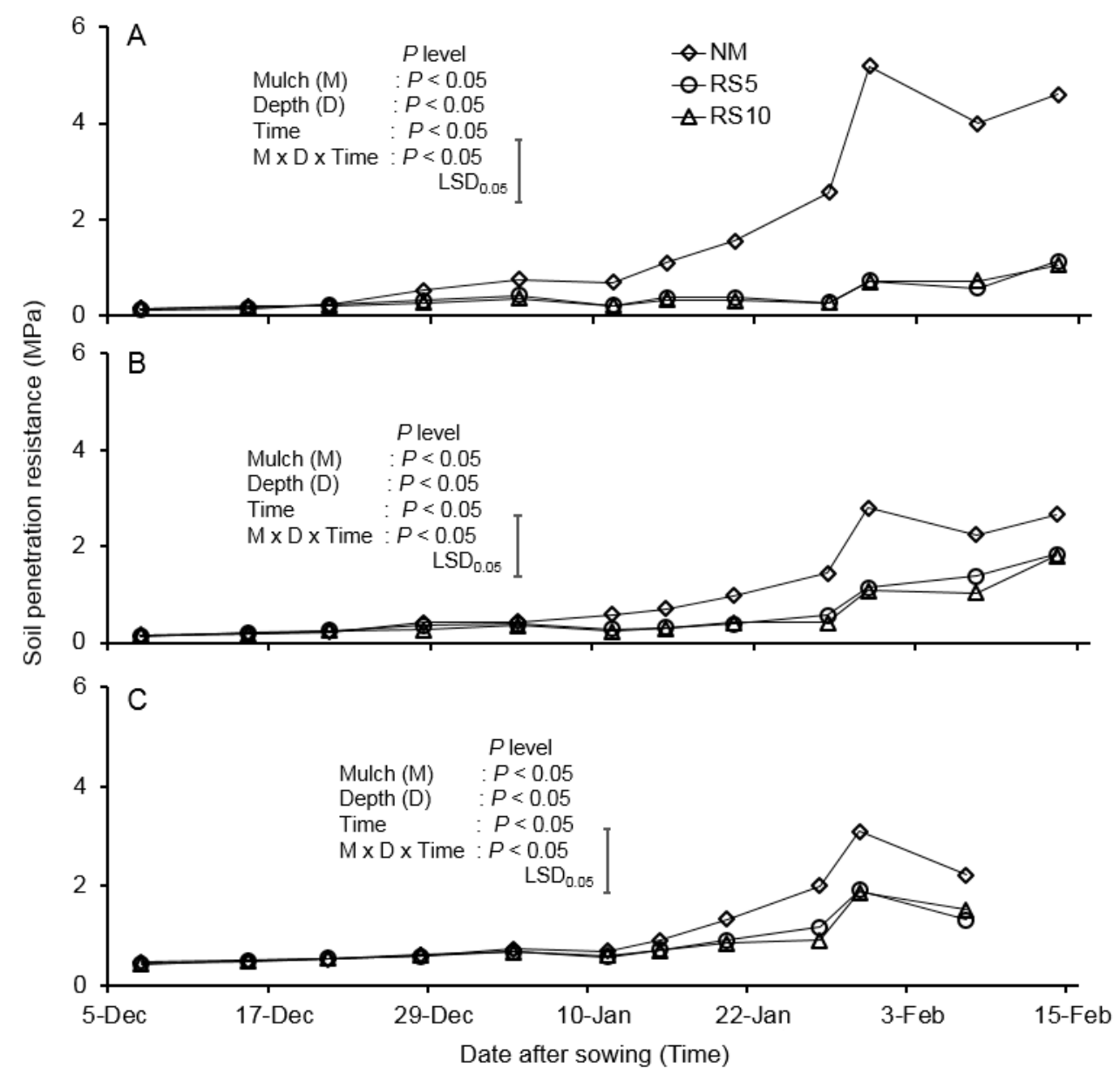

Figure 4. Effects of mulch on soil penetration resistance in the 2018-2019 season: (A) at 0-7 cm, (B) 7-15 cm, and (C) 15-30 cm. $\mathrm{LSD}_{0.05}$ is the least significant difference of the interaction between mulch, depth and time in each graph at a $p$-value of 0.05 . $\mathrm{NM}=$ no-mulch; RS5 = rice straw at $\sim 5 \mathrm{t} \mathrm{ha}^{-1}$; RS10 $=$ rice straw at $\sim 10 \mathrm{tha}^{-1}$. Note: 7 December was the sowing date for sunflower.

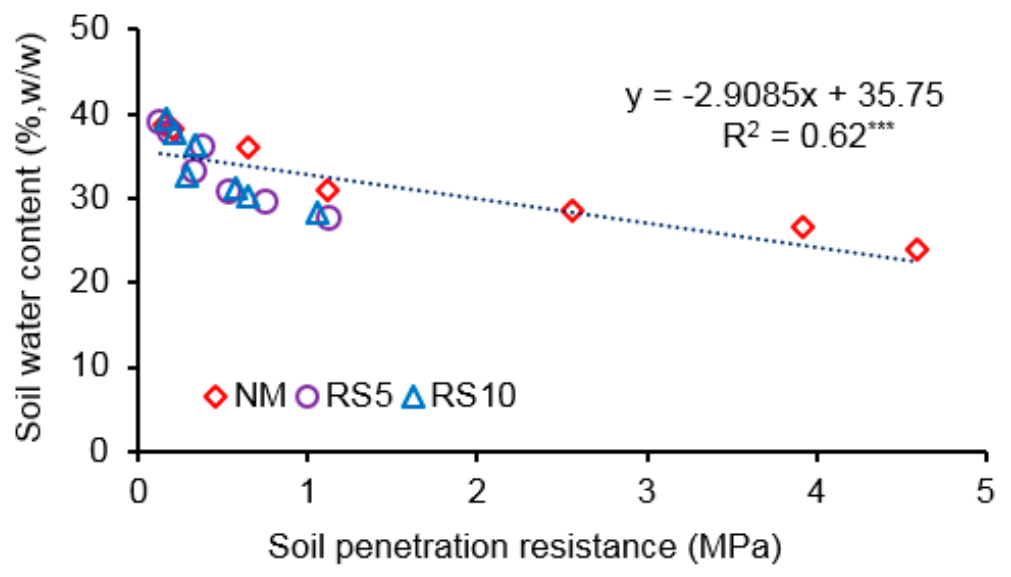

Figure 5. Relationship between average soil water content and average soil resistance $(0-30 \mathrm{~cm}$ soil depth) from sowing to bud formation. $\mathrm{NM}=$ no-mulch; RS5 = rice straw at $\sim 5 \mathrm{t} \mathrm{ha}^{-1}$; RS10 = rice straw at $\sim 10 \mathrm{tha}^{-1}$. ${ }^{* * *}$ indicates significance at $0.1 \%$ probability level.

\subsection{Soil Crack Development}

Crack measurements were started 15 days after the application of rice straw mulch. Cracks were developed in all mulch treatments but with significant differences. Initially, 
the length of crack per unit area $\left(\mathrm{L}_{\mathrm{A}}\right)$ rose rapidly to a maximum of $8-9 \mathrm{~m} \mathrm{~m}^{-2}$ with the NM treatment and afterward decreased slightly (Figure 6A). Crack length increased at a lower rate up to a peak value of 3.8 and $2.9 \mathrm{~m} \mathrm{~m}^{-2}$ under RS5 and RS10 treatments. However, the RS10 treatment (mulch at $10 \mathrm{t} \mathrm{ha}^{-1}$ ) had significantly reduced crack length compared with the RS5 treatment (mulch at $5 \mathrm{t} \mathrm{ha}^{-1}$ ). From the first measurements with the NM treatment, the mean crack width and depth were much greater than with the other mulch treatments and reached a peak at $3 \mathrm{~cm}$ (width) and $17 \mathrm{~cm}$ (depth). By contrast, cracks were both shallower and narrower with the RS5 and RS10 treatments with values that varied from $1.0-1.6 \mathrm{~cm}$ and $1.0-1.3 \mathrm{~cm}$ (width) and $6.8-9.3 \mathrm{~cm}$ and $6.4-8.2 \mathrm{~cm}$ (depth), respectively (Figure $6 \mathrm{~B}, \mathrm{C}$ ). The larger crack width and depth under the NM treatment exposed a much greater surface area of cracks compared to the RS5 and RS10 treatments (Figure 6D). From the first sampling, the rate of increase in crack volume was much faster with the NM treatment, which increased from 0.005 on 5 January to $0.02 \mathrm{~m}^{3} \mathrm{~m}^{-2}$ at the peak on 27 January (Figure 6E). By contrast, in the RS5 and RS10 treatments, the crack volume increased from 0.0009 to $0.0023 \mathrm{~m}^{3} \mathrm{~m}^{-2}$ (from 5 January to 27 January). Irrigation treatments only affected the length per unit area $\left(\mathrm{L}_{\mathrm{A}}\right)$; the I2 treatment had a significantly lower $\mathrm{L}_{\mathrm{A}}$ value $\left(4.1 \mathrm{~m} \mathrm{~m}^{-2}\right)$ than the $\mathrm{I} 1$ treatment $\left(4.5 \mathrm{~m} \mathrm{~m}^{-2}\right)$ (data not presented).
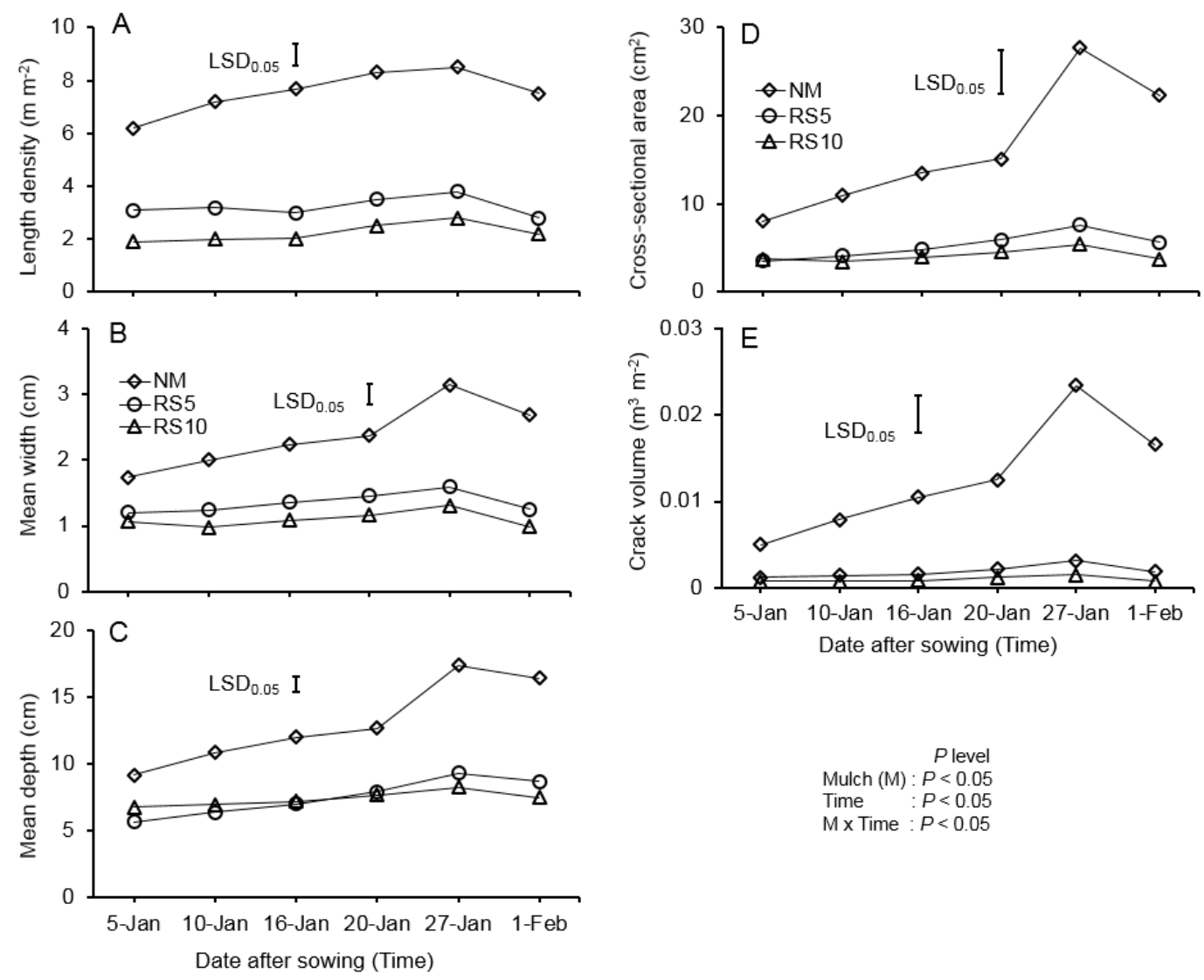

Time : $P<0.05$

Figure 6. Effects of mulch treatments on crack parameters: (A) length per unit area, (B) mean width, (C) mean depth, (D) mean cross-sectional area, and (E) crack volume per unit area. LSD $_{0.05}$ is the least significant difference of the interaction in each graph between mulch and time at a $p$-value of 0.05 . NM $=$ no-mulch; RS5 = rice straw at $\sim 5 \mathrm{tha}^{-1}$; RS10 = rice straw at $\sim 10 \mathrm{t} \mathrm{ha}^{-1}$. Note: the sunflower crop was sown on 7 December.

\subsection{Root Distribution}

The interaction of mulch and irrigation had no effects on all measures of root parameters. At the seedling stage (25 DAS), there was no effect of mulch on root distribution (data not shown), but at bud formation (58 DAS) and at flowering (90 DAS) all measures 
of root distribution were significantly affected by mulch treatments, soil depth and the interaction between mulch and depth, except that mulch had no effect on SRL at flowering (Figures 7 and 8).
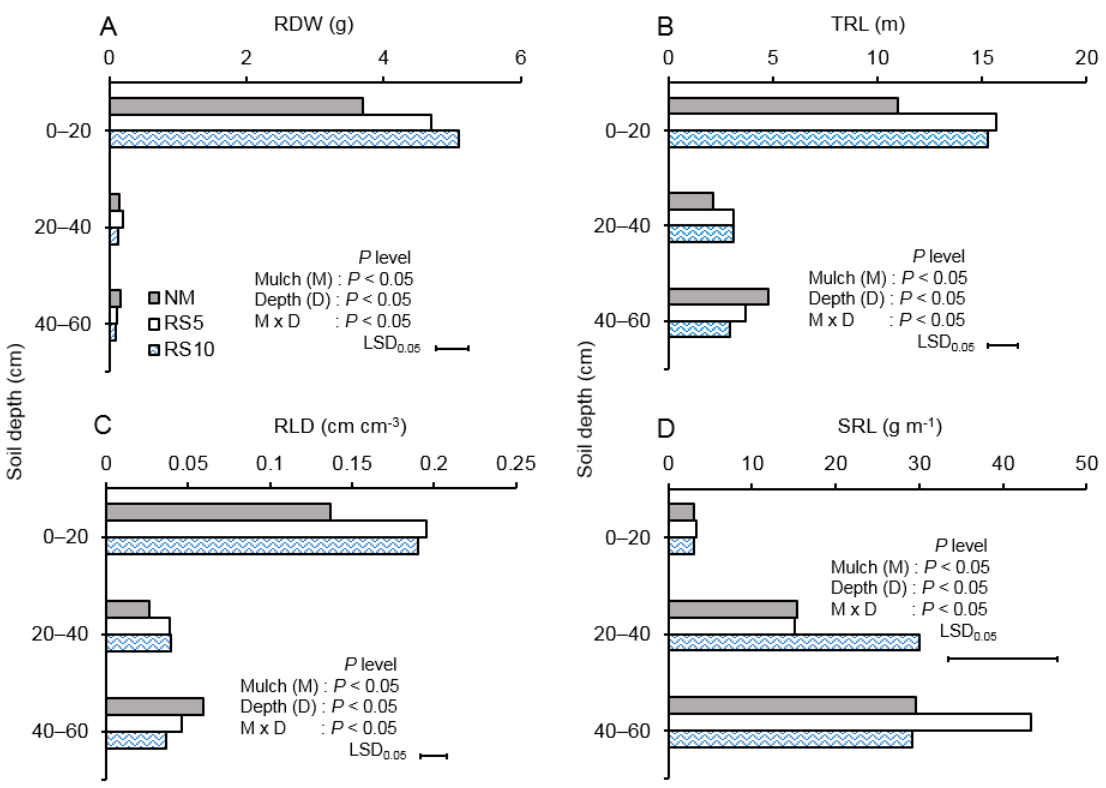

Figure 7. Effects of mulch treatments on root parameters at different soil depths at bud formation (at 58 DAS) in 2018-2019: (A) mean root dry weight (RDW), (B) total root length (TRL), (C) root length density (RLD), and (D) specific root length (SRL). SSD $_{0.05}$ is the least significant difference of the interaction between mulch and depth. $\mathrm{NM}=$ no-mulch; RS5 = rice straw $\sim 5 \mathrm{tha}^{-1}$; RS10 = rice straw $\sim 10 \mathrm{tha}^{-1}$.
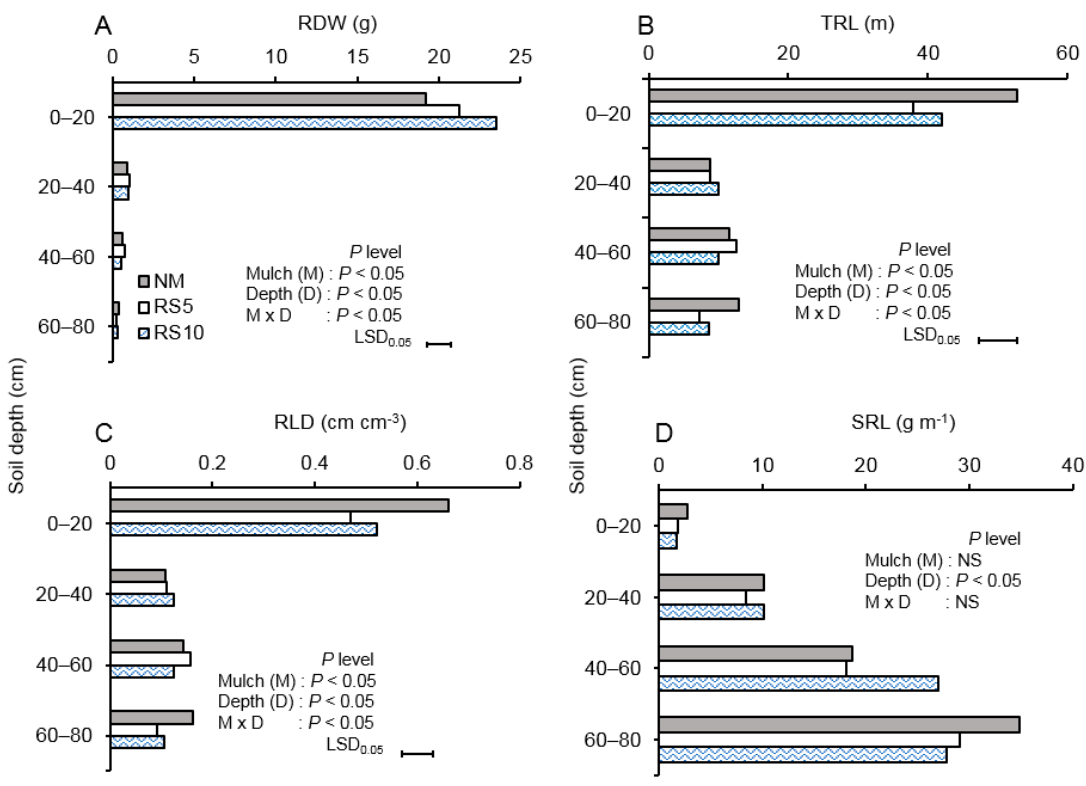

Figure 8. Effects of mulch treatments on root parameters at different soil depths at flowering (at 90 DAS) in 2018-2019: (A) mean root dry weight (RDW), (B) total root length (TRL), (C) root length density (RLD), and (D) specific root length (SRL). LSD $_{0.05}$ is the least significant difference in the interaction between mulch and depth. $\mathrm{NM}=$ no-mulch; RS5 = rice straw $\sim 5 \mathrm{tha}^{-1}$; $\mathrm{RS} 10=$ rice straw $\sim 10 \mathrm{tha}^{-1}$.

At bud formation and flowering, the RDW, TRL and RLD values were highest at $0-20 \mathrm{~cm}$ and were $71-97 \%$ lower at the deepest depth measured $(40-60 \mathrm{~cm}$ at bud formation; 
60-80 cm depth at flowering). The RS5 and RS10 treatments significantly increased RDW, TRL and RLD values at $0-20 \mathrm{~cm}$ at bud formation, but only increased RDW at $0-20 \mathrm{~cm}$ at flowering (Figures 7 and 8). On average, the RS5 and RS10 treatments had 22-38\% higher RDW compared with the NM treatment. During bud formation, the TRL was higher with RS5 and RS10 treatments than with the NM treatment at a $0-20 \mathrm{~cm}$ depth, but at a 40-60 cm depth the TRL was significantly higher with the NM treatment than RS5 and RS10 treatments (Figure 7B). On the other hand, at flowering, the NM treatment had a higher TRL at 0-20 and 60-80 cm than with the RS5 and RS10 treatments; the reason for the increase in shallow roots in the NM plots was the huge number of new adventitious roots formed near the surface after the soil was flooded due to heavy rainfall. The SRL increased with depth at bud formation and flowering. However, mulch had no effect on SRL at $0-20 \mathrm{~cm}$ at bud formation or at all depths at flowering (Figures 7D and 8D).

\subsection{Relationships between Soil Factors and Yield}

Correlations between yield and soil factors showed that yield was significantly positively correlated with the SWC, whereas yield was significantly negatively correlated with soil peneration resistance and crack factors $\left(\mathrm{r}^{2}=0.57-0.76 ; p<0.05\right)$ (Table 3). Crack parameters (length density, width, depth, area and volume) explained the most yield variation $\left(\mathrm{R}^{2}=0.55-0.58\right)$. The SWC and soil penetration resistance accounted for about $32 \%$ and $34 \%$ variation in the yield (Table 3 ).

Table 3. Relationship between yield and soil factors (soil water content, soil penetration resistance and crack parameters).

\begin{tabular}{|c|c|c|c|}
\hline Soil Factors & Correlation Coefficient $\left(\mathrm{r}^{2}\right)$ & Regression Equation & Co-Efficient Determination $\left(R^{2}\right)$ \\
\hline Soil water content (SWC) & $(+) 0.57 *$ & $Y=0.13 S W C-1.49$ & 0.32 \\
\hline Soil penetration resistance & $(-) 0.58 *$ & $\mathrm{Y}=-0.50 \mathrm{SR}+3.43$ & 0.34 \\
\hline Crack parameters & & & \\
\hline Crack length per unit area $\left(\mathrm{L}_{\mathrm{A}}\right)$ & $(-) 0.76^{* * *}$ & $Y=-0.104 \mathrm{LA}+3.43$ & 0.58 \\
\hline Crack width $(\mathrm{W})$ & (-) $0.75^{* * *}$ & $\mathrm{Y}=-0.42 \mathrm{~W}+3.65$ & 0.57 \\
\hline Crack depth (D) & (-) $0.72 * * *$ & $\mathrm{Y}=-0.09 \mathrm{D}+3.77$ & 0.53 \\
\hline Crack cross-sectional area $(\mathrm{A})$ & $(-) 0.74^{* * *}$ & $\mathrm{Y}=-446.74 \mathrm{~A}+3.35$ & 0.56 \\
\hline Crack volume $(\mathrm{V})$ & $(-) 0.74^{* * *}$ & $\mathrm{Y}=-47.52 \mathrm{~V}+3.21$ & 0.55 \\
\hline
\end{tabular}

${ }^{*}$ and ${ }^{* * *}$ indicate significance at $1 \%$ and $0.1 \%$ probability level.

There was also a significant relationship between yield and root parameters during bud formation and flowering at different depths in the soil (Table 4). The most significant impacts on yield were RDW at a $0-20 \mathrm{~cm}$ soil depth at bud formation $(p<0.001)$ and flowering $(p<0.01)$ stages, while below this depth there was no correlation. During bud formation, TRL and RLD at $0-40 \mathrm{~cm}$ were significantly $(p<0.05)$ correlated with yield, but at flowering these factors, as well as SRL, were only significant $(p<0.05)$ at a $60-80 \mathrm{~cm}$ depth (Table 4).

Table 4. Relationships between yield and root parameters at a 0-60 cm (at 58 DAS) and a 0-80 cm depth (at 90 DAS).

\begin{tabular}{|c|c|c|c|c|c|c|c|c|}
\hline \multirow{3}{*}{$\begin{array}{l}\text { Soil Depth } \\
\text { (cm) }\end{array}$} & \multicolumn{4}{|c|}{ At Bud Formation (58 DAS) } & \multicolumn{4}{|c|}{ At Flowering (90 DAS) } \\
\hline & \multicolumn{4}{|c|}{$p$-Levels and $r^{2}$ Values in Brackets } & \multicolumn{4}{|c|}{$p$-Levels and $r^{2}$ Values in Brackets } \\
\hline & RDW & TRL & RLD & SRL & RDW & TRL & RLD & SRL \\
\hline $0-20$ & $* * *(0.52)$ & * $(0.31)$ & * $(0.31)$ & NS & $* *(0.34)$ & NS & NS & $*(0.24)$ \\
\hline $20-40$ & NS & $*(0.26)$ & $*(0.26)$ & NS & NS & NS & NS & NS \\
\hline $40-60$ & NS & NS & NS & NS & NS & NS & NS & NS \\
\hline $60-80$ & - & - & - & - & NS & $*(0.22)$ & $*(0.22)$ & $* *(0.35)$ \\
\hline
\end{tabular}

$*, * *$ and ${ }^{* * *}$ indicate significance at $5 \%, 1 \%$ and $0.1 \%$ probability level. NS $=$ non-significant. 


\subsection{Effects of Cracks and Soil Penetration Resistance on Root Distribution}

In general, crack parameters (width, length density, depth, cross-sectional area and volume) had negative effects on the RDW and TRL at bud formation but not at flowering; the single exception was an effect of crack depth at flowering on TRL (Table 5). Among the crack parameters, the crack width and length area had the strongest relationships with RDW $\left(\mathrm{r}^{2}=0.72\right.$ and 0.73$)$, while there was a greater influence of crack volume on TRL $\left(r^{2}=0.54\right)$ at bud formation (Table 5$)$. Soil penetration resistance was also negatively correlated with the root distribution of sunflowers. Increasing soil penetration resistance significantly reduced the RDW and TRL at bud formation (Figure 9A,B). At flowering, RDW was also decreased with increasing soil penetration resistance, but there was no relation with TRL (Figure 9C,D).

Table 5. Significance of relationships of crack parameters to root dry weight and total root length at bud formation (average 0-60 cm) and flowering stage (average 0-80 cm soil depth).

\begin{tabular}{ccccc}
\hline Crack Parameters & $\begin{array}{c}\text { Total Root Dry } \\
\text { Weight at Bud } \\
\text { Formation }\end{array}$ & $\begin{array}{c}\text { Total Root } \\
\text { Dry Weight at } \\
\text { Flowering }\end{array}$ & $\begin{array}{c}\text { Total Root } \\
\text { Length at Bud } \\
\text { Formation }\end{array}$ & $\begin{array}{c}\text { Total Root } \\
\text { Length at } \\
\text { Flowering }\end{array}$ \\
\hline \multicolumn{4}{c}{$p$-Levels with $\mathbf{r}^{2}$ Values in Brackets } \\
\hline $\begin{array}{c}\text { Width (W) } \\
\text { Length per unit area }\end{array}$ & $* *(0.73)$ & NS & NS & NS \\
(LA) & $* *(0.72)$ & NS & $*(0.44)$ & NS \\
$\begin{array}{c}\text { Depth (D) } \\
\text { Cross-sectional area }\end{array}$ & $* *(0.68)$ & NS & $*(0.48)$ & $*(0.44)$ \\
(A) & $* *(0.67)$ & NS & $*(0.47)$ & NS \\
Volume (V) & $* *(0.66)$ & NS & $*(0.54)$ & NS \\
\hline
\end{tabular}

${ }^{*}$ and ${ }^{* *}$ indicate significance at $5 \%$ and $1 \%$ probability level. NS $=$ non-significant.
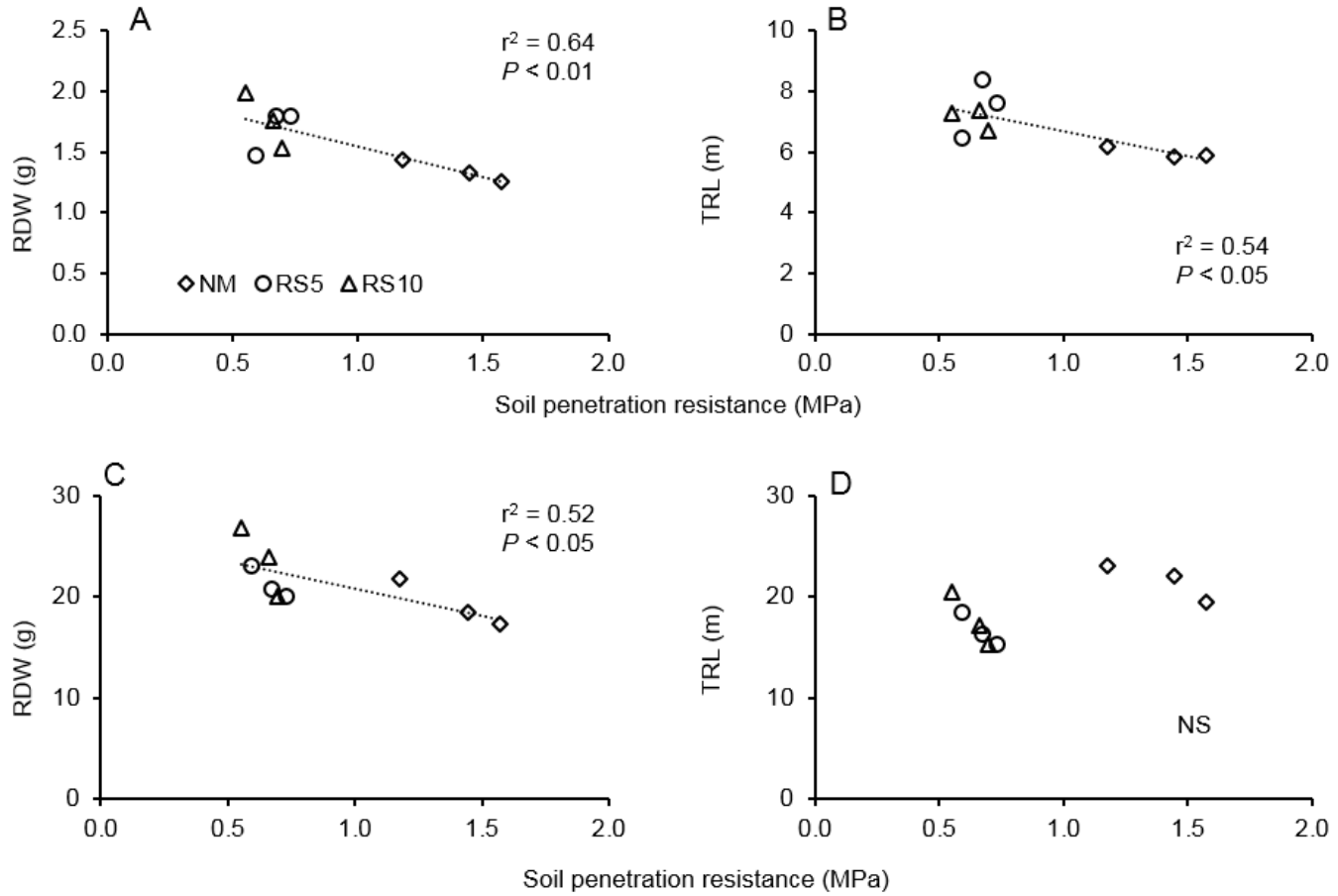

Figure 9. Relationship between average soil penetration resistance $(0-30 \mathrm{~cm})$ and root parameters in 2018-2019: (A) total root dry weight (RDW), (B) total root length (TRL) at bud formation, and (C) total root dry weight, (D) total root length at flowering. $\mathrm{NM}=$ no-mulch; RS5 $=$ rice straw $\sim 5 \mathrm{tha}^{-1} ; \mathrm{RS} 10=$ rice straw $\sim 10 \mathrm{t} \mathrm{ha}^{-1}$; $\mathrm{NS}=$ non-significant. 


\section{Discussion}

Roots are difficult to extract from clay soils in the field. As a result, relatively few field datasets exist for clay soils in which changes in rooting patterns due to subsoil constraints can be correlated with variation in crop grain yield. Figure 10 presents the key interactions between soil water content, cracks and soil penetration resistance, the production of roots and grain yield. This schematic "roadmap" shows that while soil water content was significantly correlated with grain yield $\left(\mathrm{r}^{2}=0.57 ; p<0.05\right)$, the mechanism through which this occurred may have been through the development of cracks that affected the formation of roots (crack width against total root weight at $0-60 \mathrm{~cm} \mathrm{r}^{2}=0.73 ; p<0.01$ ). The $\mathrm{r}^{2}$ (correlation coefficient) of relationships between crack or root parameters and grain yield was greater than the $\mathrm{r}^{2}$ of the relationship between soil water content and yield or soil penetration resistance and yield (Figure 10).

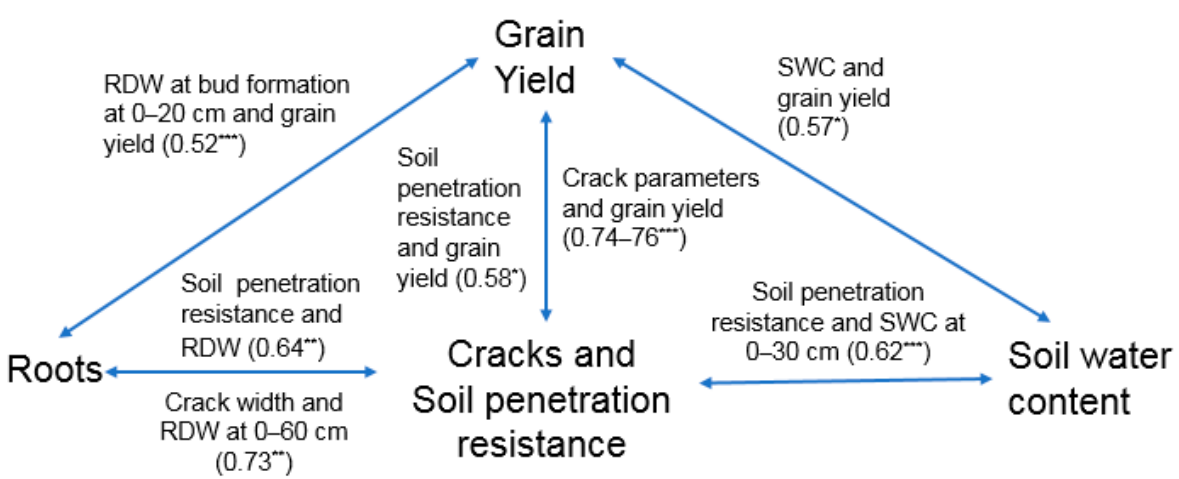

Figure 10. Schematic diagram summarizing the best relationships between the various factors studied in this paper. Values in the brackets indicate the $\mathrm{r}^{2}$ and significance of the simple linear regression between the two named variables. RDW = root dry weight; SWC $=$ soil water content. *** and ** indicate significance at $5 \%, 1 \%$ and $0.1 \%$ probability level. NS = non-significant.

In the present work, rice straw mulch $\left(5 \mathrm{tha}^{-1}\right.$ and $\left.10 \mathrm{tha}^{-1}\right)$ reduced soil cracking and soil penetration resistance and increased soil water content; these changes were associated with the increased formation of shallow roots $(0-20 \mathrm{~cm}$ depth) and a $23 \%$ increase in the yield of sunflowers. This discussion focuses on the effects of mulch on soil properties (soil water content, soil penetration resistance and crack development) and the effects of mulch and soil properties on roots and yield.

\subsection{Soil Water Content, Soil Penetration Resistance and Crack Development}

In the current study, grain yield was strongly affected by the presence of cracks and then by changes in soil resistance, and mulch ameliorated both of these. Furthermore, the use of mulch was more effective at suppressing crack formation than the use of irrigation; plots without mulch developed a substantial crack network even with two irrigation events, but plots with rice straw mulch ( $5 \mathrm{t} \mathrm{ha}^{-1}$ and $10 \mathrm{t} \mathrm{ha}^{-1}$ ) had lowered cracks developments using all the parameters we measured. The smaller amount of crack formation under rice straw mulch was associated with a higher content of surface soil water. This finding supports the previous study conducted by Bandyopadhyay [28] who reported that for clay-textured soil, crack depth, width, area and volume increased with decreasing SWC at a $0-15 \mathrm{~cm}$ soil depth. Another study at Los Banos, Philippines reported that straw mulch at $5 \mathrm{tha}^{-1}$ in a fallow rice field reduced mean crack width by around $32 \%$ but did not reduce mean crack depth compared to the no-mulch plot [12].

Soil penetration resistance was another factor that was altered by mulches. In the absence of surface cover, no-tillage cultivation in clayey soils is problematic for soil physical properties and crop production [2]. Puddled clay soils with a high content of swell-shrink clay minerals become strong and compacted when dried. At seedling stage (28 December), soil penetration resistance was $<0.5 \mathrm{MPa}$ and non-limiting to root growth. Soil penetration 
resistance was highest at the vegetative stage (30 January), when values exceeded $5 \mathrm{MPa}$ in no-mulch plots but were $1 \mathrm{MPa}$ in mulched plots at $0-7 \mathrm{~cm}$ soil depth. Although previous literature [29] pointed out that root growth was slowed by soil penetration resistance of $1 \mathrm{MPa}$ and completely ceased at $5 \mathrm{MPa}$, the high values in current study did not limit the RDW and TRL, presumably because when soil penetration resistance was high, tap roots were able to overcome the compacted layer $(0-20 \mathrm{~cm})$ and had started development into the deeper soil profile at 40-60 cm.

Throughout the season, the average soil penetration resistance was $67 \%$ lower with the RS5 and RS10 treatments than with the NM treatment. The cause of the higher soil penetration resistance with the NM treatment was mainly related to decreased soil water content (Figure 5). In line with the current study, several previous studies have reported that using mulch on bare soil can reduce soil resistance by enhancing soil water holding capacity, increasing soil porosity and improving microbial activities [30-32]. In addition, mulch has been noted to improve the mineralization of soil organic carbon and nitrogen, which leads to the stabilization of soil aggregates and the amelioration of soil penetration resistance $[33,34]$. Increasing the level of mulch from $5 \mathrm{tha}^{-1}$ to $10 \mathrm{tha}^{-1}$ and increasing the volume of irrigation water applied to the above field capacity did not affect soil penetration resistance throughout the study period.

\subsection{Root Distribution}

Data presented in this paper show that sunflower roots on clay soil are distributed according to several principles: (a) root dry mass, root length and root length density are greater at $0-20 \mathrm{~cm}$ than at depths in the soil profile, and mulches can increase root dry mass at 0-20 cm which increases grain yield; (b) roots can penetrate to considerable depths (to $80 \mathrm{~cm}$ ) in this clayey, seasonally anaerobic soil; and (c) these effects occur despite or because of the presence of soil cracks and very high soil penetration resistances.

In the present work, around $90-95 \%$ of total sunflower root biomass and $70-80 \%$ of total root length were concentrated in the $0-20 \mathrm{~cm}$ depth. Plant yield was most affected by total root dry mass at the $0-20 \mathrm{~cm}$ depth at the bud formation stage $\left(\mathrm{r}^{2}=0.52 ; p<0.001\right)$ (Table 4). At 58 and 90 DAS, some roots were found at $40-80 \mathrm{~cm}$ depth; these were not a large proportion of total root weight (3\% of those at $0-20 \mathrm{~cm}$ depth), but they were substantially finer roots at 40-80 cm than the roots at 0-20 cm, which increased SRL at 40-80 cm depth (Figures 7D and 8D). Indeed, the greater development of fine roots in the no-mulched soil may suggest that the cracks aid in deeper penetration of sunflower roots. These fine roots with a high surface area to volume ratio may be functionally important for extracting nutrients and water from the deeper layers of clay-textured soil [35] but may also have been better equipped than thick roots to glean oxygen from this hypoxic soil environment. Overall, sunflower yield was best related to the shallow roots $(0-20 \mathrm{~cm})$ (Table 4).

In our study, root distribution in the soil profile was influenced by soil cracking and penetration resistance (Table 5 and Figure 9). How is it that fine roots are able to grow to depths of $80 \mathrm{~cm}$ in this massive soil that is anaerobic immediately after the rice phase and presumably also anaerobic at depth in the rabi season? We wonder if the development of cracks as the soil dries provides an opportunity for roots to receive sufficient oxygen for metabolism from the soil adjacent to the crack void and if a low soil strength in the wet sub-soil allows root to elongate. Given this, we might expect that roots would be located in the soil close to the cracks within the massive blocks of clay between the cracks.

One interesting feature of the current experiment was how late season waterlogging affected root growth. Waterlogging due to heavy rainfall can change root distribution [36]. In the present work, after the heavy rain $(175 \mathrm{~mm})$ at flowering, adventitious roots were produced more abundantly at a $0-20 \mathrm{~cm}$ soil depth on the no-mulch plot resulting in a higher TRL and RLD than in the mulched plots. Despite this adventitious root formation, RDW was still greater with the RS5 and RS10 treatments than the NM treatment at the 0-20 cm soil depth. On the other hand, despite the greater abundance of fine roots at 
40-80 cm under no-mulch as compared to the mulch plots, they were not able to compensate for lower root growth in the $0-20 \mathrm{~cm}$ layer, possibly because the deeper roots formed too late in the growing season.

Although root growth is negatively affected by compacted soil, there is a good evidence that plants have adaptations to cope with increasing soil penetration resistance [37]. In strong soil, the primary roots of plants can be thicker and shorter, and tap roots can be grown more rapidly than in normal soil $[10,26]$. However, lateral roots can be thinner, which enables the tips to find cracks, void and smaller pores to penetrate through hard layers, including plough pans [38-40]. As the highest soil penetration was at a $0-7 \mathrm{~cm}$ depth and decreased further down the soil profile in the no-mulch plot, roots grew into the weaker sub-soil after exiting the surface layer of strong soil because of the increase in the availability of soil water with depth.

\subsection{Sunflower Growth and Yield}

In the present work, using rice straw mulch $\left(5\right.$ and $\left.10 \mathrm{t} \mathrm{ha}^{-1}\right)$ on clay-textured soil increased sunflower yield by around $23 \%$ and increased seeds per head by $15 \%$ compared to the no-mulch treatment. The higher yield and yield components under straw mulch were attributed to the decreased crack formation and lower soil penetration resistance (associated with higher SWC), which enhanced dry root weight and total root length. The yield was highly correlated with crack parameters and to a lesser extent soil penetration resistance and SWC. This yield improvement is of a similar scale to other examples in the literature. At the same location, a previous study showed that straw mulch at $\sim 5 \mathrm{tha}^{-1}$ boosted sunflower yield by $16-26 \%$ relative to no-mulch [20]. So and Ringrose-Voase [32] also reported that using rice straw mulch at $5 \mathrm{tha}^{-1}$ in strongly compacted soil increased mungbean yield by $30 \%$ in Indonesia.

\section{Conclusions}

Soil shrinkage and crack development during the drying of puddled clay soil were related to increased soil penetration resistance and reduced root growth and development of sunflowers in the upper $20 \mathrm{~cm}$ of soil. In the present work, rice straw mulch at $5 \mathrm{tha}^{-1}$ increased soil water content while also reducing soil penetration resistance and cracking in the surface soil. Improvement of the soil's physical properties and a higher root biomass in the $0-20 \mathrm{~cm}$ soil depth under the rice straw mulch increased the sunflower yield by $23 \%$. No further benefits (for soil penetration resistance and sunflower growth and yield) were obtained by increasing the mulch level from 5 to $10 \mathrm{tha}^{-1}$ or by increasing the volume of irrigation water. Thus, ameliorating soil physical constraints in clay soils of the coastal zone of the Ganges Delta increased root growth at the $0-20 \mathrm{~cm}$ soil depth and consequently increased sunflower yield.

Author Contributions: Conceptualization, P.L.C.P.: methodology, P.L.C.P.; software, P.L.C.P.; validation, P.L.C.P.; formal analysis, P.L.C.P.; investigation, P.L.C.P., R.W.B., E.G.B.-L. and E.K.; data curation, P.L.C.P. and R.W.B.; writing—original draft, P.L.C.P.; writing—review and editing, R.W.B., E.G.B.-L. and E.K.; visualization, P.L.C.P.; supervision, R.W.B., E.G.B.-L. and E.K.; project administration, R.W.B.; fuding acquisition, P.L.C.P., R.W.B., E.G.B.-L. and E.K. All authors have read and agreed to the published version of the manuscript.

Funding: This research was funded by Australian Center for International Agricultural Research (ACIAR), grant number LWR/2014/073.

Institutional Review Board Statement: Not applicable.

Informed Consent Statement: Not applicable.

Data Availability Statement: The analyzed datasets are available from the corresponding author on reasonable request.

Acknowledgments: We would like to thank the Australian Centre for International Agricultural Research (ACIAR) (Project LWR/2014/073) for funding this research work and for a John Allwright 
Fellowship to the senior author. We are grateful to the Soil Science Division laboratory and Irrigation and Water Management Division, Bangladesh Rice Research Institute, Bangladesh for their kind support to analyse soil samples. Al Imran Malik is acknowledged for his reviewing the manuscript.

Conflicts of Interest: The authors declare that they have no conflict of interest.

\section{References}

1. Mondal, M.K.; Paul, P.L.C.; Humphreys, E.; Tuong, T.P.; Ritu, S.P.; Rashid, M.A. Opportunities for cropping system intensification in the coastal zone of Bangladesh. In Proceedings of the CPWF, GBDC, WLE Conference on Revitalizing the Ganges Coastal Zone: Turning Science into Policy and Practices, Dhaka, Bangladesh, 21-23 October 2015; Humphreys, E., Tuong, T.P., Buisson, M.-C., Pukinskis, I., Phillips, M., Eds.; CGIAR Challenge Program on Water and Food (CPWF): Colombo, SriLanka, 2015 ; pp. 449-476.

2. Paul, P.L.C.; Bell, R.W.; Barrett-Lennard, E.G.; Kabir, E. Variation in the yield of sunflower (Helianthus annuus L.) due to differing tillage systems is associated with variation in solute potential of the soil solution in a salt-affected coastal region of the Ganges Delta. Soil Tillage Res. 2020, 197, 104489. [CrossRef]

3. Adachi, T. Effects of rice-soil puddling on water percolation. In Proceedings of the Transactions of the 14th International Congress of Soil Science, Kyoto, Japan, August 1990.

4. Kirchhof, G.; So, H.; Adisarwanto, T.; Utomo, W.; Priyono, S.; Prastowo, B.; Basir, M.; Lando, T.; Subandi; Dacanay, E.; et al. Growth and yield response of grain legumes to different soil management practices after rainfed lowland rice. Soil Tillage Res. 2000, 56, 51-66. [CrossRef]

5. Bayhan, Y.; Kayisoglu, B.; Gonulol, E. Effect of soil compaction on sunflower growth. Soil Tillage Res. 2002, 68, 31-38. [CrossRef]

6. Cambi, M.; Mariotti, B.; Fabiano, F.; Maltoni, A.; Tani, A.; Foderi, C.; Laschi, A.; Marchi, E. Early response of Quercus robur seedlings to soil compaction following germination. Land Degrad. Dev. 2018, 29, 916-925. [CrossRef]

7. Kozlowski, T.T. Soil Compaction and Growth of Woody Plants. Scand. J. Forest Res. 1999, 14, 596-619.

8. Cook, S. Soil physical constraints to establishment of mungbeans (Vigna radiata L. Wilczek) in paddy rice (Oryza sativa L.) soils. Soil Tillage Res. 1995, 33, 47-64. [CrossRef]

9. So, H.; Woodhead, T. Alleviation of soil physical limits to productivity of legumes in Asia. In Proceedings of the International Workshop, Khon Kaen, Thailand, 1-5 September 1987.

10. Goodman, A.; Ennos, A.R. The Effects of Soil Bulk Density on the Morphology and Anchorage Mechanics of the Root Systems of Sunflower and Maize. Ann. Bot. 1999, 83, 293-302. [CrossRef]

11. Moslehuddin, A.Z.; Hussain, M.S.; Saheed, S.M.; Egashira, K. Clay mineral distribution in correspondence with agroecological regions of Bangladesh soils. Clay Sci. 1999, 11, 83-94.

12. Cabangon, R.J.; Tuong, T. Management of cracked soils for water saving during land preparation for rice cultivation. Soil Tillage Res. 2000, 56, 105-116. [CrossRef]

13. Tuong, T.P.; Cabangon, R.J.; Wopereis, M.C.S. Quantifying Flow Processes during Land Soaking of Cracked Rice Soils. Soil Sci. Soc. Am. J. 1996, 60, 872-879. [CrossRef]

14. Wopereis, M.; Bouma, J.; Kropff, M.; Sanidad, W. Reducing bypass flow through a dry, cracked and previously puddled rice soil. Soil Tillage Res. 1994, 29, 1-11. [CrossRef]

15. Ringrose-Voase, A.; Sanidad, W. A method for measuring the development of surface cracks in soils: Application to crack development after lowland rice. Geoderma 1996, 71, 245-261. [CrossRef]

16. Taylor, H.; Brar, G. Effect of soil compaction on root development. Soil Tillage Res. 1991, 19, 111-119. [CrossRef]

17. Whitmore, A.P.; Whalley, W.R. Physical effects of soil drying on roots and crop growth. J. Exp. Bot. 2009, 60, 2845-2857. [CrossRef]

18. Aasegawa, S.; Thangaraj, J.M.; O'Toole, J. Root behavior: Field and laboratory studies for rice and nonrice crops. Soil Phys. Rice 1985, 6, 383.

19. Jourgholami, M.; Nasirian, A.; Labelle, E.R. Ecological Restoration of Compacted Soil Following the Application of Different Leaf Litter Mulches on the Skid Trail over a Five-Year Period. Sustain. J. Rec. 2018, 10, 2148. [CrossRef]

20. Paul PL, C.; Bell, R.W.; Barrett-Lennard, E.G.; Kabir, E. Straw mulch and irrigation affect solute potential and sunflower yield in a heavy textured soil in the Ganges Delta. Agric. Water. Manag. 2020, 239, 106211. [CrossRef]

21. Fang, S.; Xie, B.; Liu, D.; Liu, J. Effects of mulching materials on nitrogen mineralization, nitrogen availability and poplar growth on degraded agricultural soil. New For. 2011, 41, 147-162. [CrossRef]

22. Mulumba, L.N.; Lal, R. Mulching effects on selected soil physical properties. Soil Tillage Res. 2008, 98, 106-111. [CrossRef]

23. Lal, R.; Latham, M. Management of soil compaction and soil-water after forest clearing in upland soils of humic tropical Asia. Soil Manag. Humid Cond. Asia Pac. 1987, 5, 273-296.

24. Mitchell, J.; Cheth, K.; Seng, V.; Lor, B.; Ouk, M.; Fukai, S. Wet cultivation in lowland rice causing excess water problems for the subsequent non-rice crops in the Mekong region. Field Crop. Res. 2013, 152, 57-64. [CrossRef]

25. Tracy, S.R.; Black, C.R.; A Roberts, J.; Mooney, S.J. Soil compaction: A review of past and present techniques for investigating effects on root growth. J. Sci. Food Agric. 2011, 91, 1528-1537. [CrossRef] 
26. Mondal, M.K.; Saha, N.K.; Ritu, S.P.; Paul, P.L.C.; Sharifullah, A.K.M.; Humphreys, E.; Tuong, T.P.; Rashid, M.A. Optimum sowing window for boro cultivation in the coastal zone of Bangladesh. In Proceedings of the CPWF, GBDC, WLE Conference on Revitalizing the Ganges Coastal Zone: Turning Science into Policy and Practices, Dhaka, Bangladesh, 21-23 October 2015; Humphreys, E., Tuong, T.P., Buisson, M.-C., Pukinskis, I., Phillips, M., Eds.; CGIAR Challenge Program on Water and Food (CPWF): Colombo, SriLanka, 2015; pp. 449-476.

27. Sarker, K.K.; Hossain, A.; Timsina, J.; Biswas, S.K.; Malone, S.L.; Alam, K.; Loescher, H.W.; Bazzaz, M. Alternate furrow irrigation can maintain grain yield and nutrient content, and increase crop water productivity in dry season maize in sub-tropical climate of South Asia. Agric. Water Manag. 2020, 238, 106229. [CrossRef]

28. Bandyopadhyay, K.; Mohanty, M.; Painuli, D.; Misra, A.; Hati, K.; Mandal, K.; Ghosh, P.; Chaudhary, R.; Acharya, C. Influence of tillage practices and nutrient management on crack parameters in a Vertisol of central India. Soil Tillage Res. 2003, 71, 133-142. [CrossRef]

29. Passioura, J.B. Soil conditions and plant growth. Plant Cell Environ. 2002, 25, 311-318. [CrossRef]

30. Jourgholami, M.; Fathi, K.; Labelle, E.R. Effects of litter and straw mulch amendments on compacted soil properties and Caucasian alder (Alnus subcordata) growth. New For. 2020, 51, 349-365. [CrossRef]

31. Liu, T.; Wang, B.; Xiao, H.; Wang, R.; Yang, B.; Cao, Q.; Cao, Y. Differentially improved soil microenvironment and seedling growth of Amorpha fruticosa by plastic, sand and straw mulching in a saline wasteland in northwest China. Ecol. Eng. 2018, 122, 126-134. [CrossRef]

32. So, H.; Ringrose-Voase, A.; Ringrose-Voase, A. Management of clay soils for rainfed lowland rice-based cropping systems: An overview. Soil Tillage Res. 2000, 56, 3-14. [CrossRef]

33. Garcia-Orenes, F.; Roldan, A.; Mataix-Solera, J.; Cerdà, A.; Campoy, M.; Arcenegui, V.; Caravaca, F. Soil structural stability and erosion rates influenced by agricultural management practices in a semi-arid Mediterranean agro-ecosystem. Soil Use Manag. 2012, 28, 571-579. [CrossRef]

34. Jordán, A.; Zavala, L.M.; Gil, J. Effects of mulching on soil physical properties and runoff under semi-arid conditions in southern Spain. Catena 2010, 81, 77-85. [CrossRef]

35. Ostonen, I.; Püttsepp, Ü.; Biel, C.; Alberton, O.; Bakker, M.R.; Lõhmus, K.; Majdi, H.; Metcalfe, D.; Olsthoorn, A.F.M.; Pronk, A.; et al. Specific root length as an indicator of environmental change. Plant Biosyst. Int. J. Deal. all Asp. Plant Biol. 2007, 141, 426-442. [CrossRef]

36. Grzesiak, M.T.; Ostrowska, A.; Hura, K.; Rut, G.; Janowiak, F.; Rzepka, A.; Hura, T.; Grzesiak, S. Interspecific differences in root architecture among maize and triticale genotypes grown under drought, waterlogging and soil compaction. Acta Physiol. Plant. 2014, 36, 3249-3261. [CrossRef]

37. Clark, L.; Whalley, W.; Barraclough, P. How do roots penetrate strong soil? Plant Soil 2003, 255, 93-104. [CrossRef]

38. Atwell, B. Physiological responses of lupin roots to soil compaction. In Structural and Functional Aspects of Transport in Roots; Springer: Dordrecht, The Netherlands, 1989; pp. 251-255.

39. Croser, C.; Bengough, A.G.; Pritchard, J. The effect of mechanical impedance on root growth in pea (Pisum sativum). I. Rates of cell flux, mitosis, and strain during recovery. Physiol. Plant. 1999, 107, 277-286. [CrossRef]

40. Goss, M. Effects of Mechanical Impedance on Root Growth in Barley (Hordeum vulgare L.). J. Exp. Bot. 1977, 28, 96-111. [CrossRef] 